\title{
Front Matter: Volume 8817
}

, "Front Matter: Volume 8817," Proc. SPIE 8817, Nanobiosystems:

Processing, Characterization, and Applications VI, 881701 (8 October 2013); doi: $10.1117 / 12.2033967$

SPIE Event: SPIE NanoScience + Engineering, 2013, San Diego, California, United SPIE. States 


\title{
PROCEEDINGS OF SPIE
}

\section{Nanobiosystems: Processing, Characterization, and Applications VI}

\author{
Norihisa Kobayashi \\ Fahima Ouchen \\ lleana Rau \\ Editors
}

25-26 and 28 August 2013

San Diego, California, United States

Sponsored and Published by

SPIE 
The papers included in this volume were part of the technical conference cited on the cover and title page. Papers were selected and subject to review by the editors and conference program committee. Some conference presentations may not be available for publication. The papers published in these proceedings reflect the work and thoughts of the authors and are published herein as submitted. The publisher is not responsible for the validity of the information or for any outcomes resulting from reliance thereon.

Please use the following format to cite material from this book:

Author(s), "Title of Paper," in Nanobiosystems: Processing, Characterization, and Applications VI, edited by Norihisa Kobayashi, Fahima Ouchen, lleana Rau, Proceedings of SPIE Vol. 8817 (SPIE, Bellingham, WA, 2013) Article CID Number.

ISSN: 0277-786X

ISBN: 9780819496676

Published by

SPIE

P.O. Box 10, Bellingham, Washington 98227-0010 USA

Telephone +1 3606763290 (Pacific Time) · Fax +1 3606471445

SPIE.org

Copyright (C) 2013, Society of Photo-Optical Instrumentation Engineers.

Copying of material in this book for internal or personal use, or for the internal or personal use of specific clients, beyond the fair use provisions granted by the U.S. Copyright Law is authorized by SPIE subject to payment of copying fees. The Transactional Reporting Service base fee for this volume is $\$ 18.00$ per article (or portion thereof), which should be paid directly to the Copyright Clearance Center (CCC), 222 Rosewood Drive, Danvers, MA 01923. Payment may also be made electronically through CCC Online at copyright.com. Other copying for republication, resale, advertising or promotion, or any form of systematic or multiple reproduction of any material in this book is prohibited except with permission in writing from the publisher. The CCC fee code is 0277-786X/13/\$18.00.

Printed in the United States of America.

Publication of record for individual papers is online in the SPIE Digital Library.

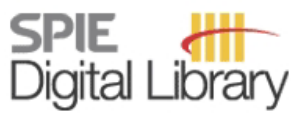

SPIEDigitalLibrary.org

Paper Numbering: Proceedings of SPIE follow an e-First publication model, with papers published first online and then in print and on CD-ROM. Papers are published as they are submitted and meet publication criteria. A unique, consistent, permanent citation identifier (CID) number is assigned to each article at the time of the first publication. Utilization of CIDs allows articles to be fully citable as soon as they are published online, and connects the same identifier to all online, print, and electronic versions of the publication. SPIE uses a six-digit CID article numbering system in which:

- The first four digits correspond to the SPIE volume number.

- The last two digits indicate publication order within the volume using a Base 36 numbering

system employing both numerals and letters. These two-number sets start with 00, 01, 02, 03, 04, $05,06,07,08,09,0 A, 0 B \ldots 0 Z$, followed by 10-1Z, 20-2Z, etc.

The CID Number appears on each page of the manuscript. The complete citation is used on the first page, and an abbreviated version on subsequent pages. Numbers in the index correspond to the last two digits of the six-digit CID Number. 


\section{Contents}

vii Conference Committee

SESSION 1

881702 Nanoengineered self-assembled two-dimensional and three-dimensional materials (Keynote Paper) [8817-1]

R. O. Claus, J. H. Lalli, V. Baranauskas, NanoSonic, Inc. (United States)

881705 Fabrication and characterization of OTFT memory based on DNA gate dielectric [8817-4]

L. Liang, T. Yukimoto, Chiba Univ. (Japan); S. Uemura, T. Kamata, National Institute of Advanced Industrial Science and Technology (Japan); K. Nakamura, N. Kobayashi, Chiba Univ. (Japan)

\section{SESSION 2}

881706 Biological and biologically inspired photonic materials and devices (Keynote Paper) [8817-5]

R. A. Norwood, College of Optical Sciences, The Univ. of Arizona (United States)

881707 Grating formation in bi-layered DNA-complex devices: application to thin-film tunable dye lasers (Invited Paper) [8817-6]

Y. Kawabe, T. Chida, T. Matsuoka, K. Fukuzawa, K. Tada, Chitose Institute of Science and Technology (Japan)

881708 DNA hybrid dielectric film devices for energy storage and bioelectronics applications (Invited Paper) [8817-7]

D. M. Joyce, Air Force Research Lab. (United States); N. Venkat, F. Ouchen, Air Force Research Lab. (United States) and Univ. of Dayton Research Institute (United States);

K. M. Singh, Air Force Research Lab. (United States) and UES, Inc. (United States);

S. R. Smith, Air Force Research Lab. (United States) and Univ. of Dayton Research Institute (United States); J. G. Grote, Air Force Research Lab. (United States)

SESSION 3

8817 OA Random lasing in bio-polymeric dye-doped systems (Invited Paper) [8817-9]

J. Mysliwiec, L. Sznitko, K. Cyprych, A. Szukalski, A. Miniewicz, Wroclaw Univ. of Technology

(Poland); F. Kajzar, I. Rau, Univ. Politehnica of Bucharest (Romania) 
8817 OB Effect of UV-crosslinking of DNA-CTMA biopolymer on its electrical and optical properties (Invited Paper) [8817-10]

F. Ouchen, N. Venkat, Univ. of Dayton Research Institute (United States) and Air Force Research Lab. (United States); P. P. Yaney, Univ. of Dayton (United States) and Air Force Research Lab. (United States); A. Lesko, Univ. of Dayton (United States); E. M. Heckman, J. G. Grote, Air Force Research Lab. (United States)

\section{SESSION 4}

8817 OC Investigation of DNA nucleobases-thin films for potential application in electronics and photonics (Keynote Paper) [8817-20]

F. Ouchen, Univ. of Dayton Research Institute (United States) and Air Force Research Lab. (United States); E. Gomez, Univ. of Cincinnati (United States); D. Joyce, Air Force Research Lab. (United States); P. Yaney, Univ. of Dayton Research Institute (United States) and Air Force Research Lab. (United States); S. Kim, A. Williams, Air Force Research Lab. (United States); A. Steckl, Univ. of Cincinnati (United States); N. Venkat, Univ. of Dayton Research Institute (United States) and Air Force Research Lab. (United States); J. Grote, Air Force Research Lab. (United States)

8817 OD Grating inscription in DR1:DNA-CTMA thin films: theory and experiment (Invited Paper) [8817-12]

G. Pawlik, W. Radosz, Wroclaw Univ. of Technology (Poland); A. C. Mitus, J. Mysliwiec, Wroclaw Univ. of Technology (Poland) and Univ. Politehnica of Bucharest (Romania); A. Miniewicz, Wroclaw Univ. of Technology (Poland); F. Kajzar, Univ. Politehnica of Bucharest (Romania) and Institut des Sciences et Technologies Moléculaires d'Angers, CNRS, Univ. d'Angers (France); I. Rau, Univ. Politehnica of Bucharest (Romania)

8817 OE Spectral investigations on binding of DNA-CTMA complex with tetrameric copper phthalocyanines (Invited Paper) [8817-13]

N. Venkat, Air Force Research Lab. (United States) and Univ. of Dayton Research Institute (United States); J. E. Haley, Air Force Research Lab. (United States); R. Swiger, Air Force Research Lab. (United States) and Southwestern Ohio Council for Higher Education (United States); L. Zhu, X. Wei, Case Western Reserve Univ. (United States); F. Ouchen, Air Force Research Lab. (United States) and Univ. of Dayton Research Institute (United States); J. G. Grote, Air Force Research Lab. (United States)

\section{SESSION 5}

8817 Ol Preliminary electrical and Raman characterization of DNA-CTMA films fabricated by drawndown bar [8817-17] P. P. Yaney, Univ. of Dayton (United States); F. Ouchen, J. G. Grote, Air Force Research Lab. (United States)

8817 0J Improving energy transfer in QD-DNA photonic networks [8817-18]

S. Buckhout-White, George Mason Univ. (United States) and U.S. Naval Research Lab. (United States); C. Spillmann, M. Ancona, U.S. Naval Research Lab. (United States); W. R. Algar, George Mason Univ. (United States) and U.S. Naval Research Lab. (United States); M. H. Stewart, K. Susumu, A. Huston, E. R. Goldman, I. L. Medintz, U.S. Naval Research Lab. (United States) 
8817 OL Investigation of maple-deposited DNA films for graphene-based device applications (Invited Paper) [8817-11]

A. Williams, A. Campbell, Air Force Research Lab. (United States); F. Ouchen, Air Force Research Lab. (United States) and Univ. of Dayton Research Institute (United States); W. LU, Air Force Research Lab. (United States) and Universal Technology Corp. (United States); J. Grant, Air Force Research Lab. (United States) and Univ. of Dayton Research Institute (United States); J. Grote, Air Force Research Lab. (United States)

\section{SESSION 6}

$88170 \mathrm{M}$ Second harmonic generation from tyrosine containing peptides (Invited Paper) [8817-21] M. N. Nasir, Institut de Chimie et Biochimie Moléculaires et Supramoléculaires, CNRS, Univ. Claude Bernard Lyon 1 (France); E. Bergmann, E. Benichou, I. Russier-Antoine, N. Lascoux, C. Jonin, Institut Lumière Matière, CNRS, Univ. Claude Bernard Lyon 1 (France); F. Besson, Institut de Chimie et Biochimie Moléculaires et Supramoléculaires, CNRS, Univ. Claude Bernard Lyon 1 (France); P. F. Brevet, Institut Lumière Matière, CNRS, Univ. Claude Bernard Lyon 1 (France)

8817 ON Bacteriorhodopsin-based bipolar photosensor for biomimetic sensing (Invited Paper) [8817-22]

K. Kasai, National Institute of Information and Communications Technology (Japan); Y. Haruyama, National Institute of Information and Communications Technology (Japan) and Osaka City Univ. (Japan); T. Yamada, M. Akiba, Y. Tominari, T. Kaji, T. Terui, F. Peper, S. Tanaka, Y. Katagiri, National Institute of Information and Communications Technology (Japan); H. Kikuchi, NHK Science \& Technical Research Labs. (Japan); Y. Okada-Shudo, The Univ. of Electro-Communications (Japan); A. Otomo, National Institute of Information and Communications Technology (Japan)

$881700 \quad$ Enhancing molecular logic through modulation of temporal and spatial constraints with quantum dot-based systems that use fluorescent (Förster) resonance energy transfer [8817-23]

J. C. Claussen, U.S. Naval Research Lab. (United States) and George Mason Univ. (United States); W. R. Algar, The Univ. of British Columbia (Canada); N. Hildebrandt, Institut d'Électronique Fondamentale, Univ. Paris Sud (France); K. Susumu, U.S. Naval Research Lab. (United States) and Sotera Defense Solutions (United States); M. G. Ancona, I. L. Medintz, U.S. Naval Research Lab. (United States)

8817 OP SFG characterization of a cationic ONLO dye in biological thin films [8817-24] L. E. Johnson, Pomona College (United States) and Univ. of Washington (United States); M. T. Casford, Univ. of Cambridge (United Kingdom); D. L. Elder, Univ. of Washington (United States); P. B. Davies, Univ. of Cambridge (United Kingdom); M. S. Johal, Pomona College (United States)

$88170 Q \quad$ Integration of biological photonic crystals in dye-sensitized solar cells for enhanced photocurrent generation [8817-25]

J. Campbell, G. Rorrer, Oregon State Univ. (United States) 
POSTER SESSION

8817 OR Protein 'smart' micro/nano-biooptics via femtosecond laser direct writing [8817-26]

Y.-L. Sun, W.-F. Dong, H.-B. Sun, Jilin Univ. (China)

8817 OV Effect of the surface plasmon on second harmonic generation from tyrosine [8817-31]

E. Bergmann, E. Benichou, I. Russier-Antoine, N. Lascoux, C. Jonin, P. F. Brevet, Institut Lumière Matière, CNRS, Univ. Claude Bernard Lyon 1 (France)

Author Index 


\title{
Conference Committee
}

\author{
Symposium Chairs
}

Satoshi Kawata, Osaka University (Japan)

Manijeh Razeghi, Northwestern University (United States)

Symposium Cochairs

David L. Andrews, University of East Anglia Norwich (United Kingdom)

James G. Grote, Air Force Research Laboratory (United States)

Conference Chairs

Norihisa Kobayashi, Chiba University (Japan)

Fahima Ouchen, Air Force Research Laboratory (United States)

lleana Rau, Polytechnical University of Bucharest (Romania)

Conference Program Committee

Carrie M. Bartsch, Air Force Research Laboratory (United States)

Liming Dai, Case Western Reserve University (United States)

Ananth Dodabalapur, The University of Texas at Austin (United States)

James G. Grote, Air Force Research Laboratory (United States)

Emily M. Heckman, Air Force Research Laboratory (United States)

Kuniharu ljiro, Hokkaido University (Japan)

Jung-II Jin, Korea University (Korea, Republic of)

Francois Kajzar, Polytechnical University of Bucharest (Romania)

Sang Nyon Kim, Air Force Research Laboratory (United States)

Oksana Krupka, Université d'Angers (France)

Charles Y. C. Lee, Air Force Office of Scientific Research (United States)

Misoon Y. Mah, Asian Office of Aerospace Research and Development (Japan)

Naoya Ogata, Chitose Institute of Science and Technology (Japan)

Bruce H. Robinson, University of Washington (United States)

Anna Samoc, The Australian National University (Australia)

Marek J. Samoc, Wroclaw University of Technology (Poland)

Niyazi Serdar Sariciftci, Johannes Kepler Universität Linz (Austria)

Kristi M. Singh, Air Force Research Laboratory (United States)

Andrew J. Steckl, University of Cincinnati (United States)

Morley O. Stone, Air Force Research Laboratory (United States)

Perry P. Yaney, University of Dayton (United States) 


\section{Session Chairs}

1 Session 1

Norihisa Kobayashi, Chiba University (Japan)

2 Session 2

Jaroslaw Mysliwiec, Wroclaw University of Technology (Poland)

3 Session 3

Ileana Rau, Polytechnical University of Bucharest (Romania)

4 Session 4

Fahima Ouchen, Air Force Research Laboratory (United States)

5 Session 5

Pierre-François Brevet, Université Claude Bernard Lyon 1 (France)

6 Session 6

Donna M. Joyce, Air Force Research Laboratory (United States) 